\title{
Neuropharmacology and Toxicology
}

National Cancer Institute

\section{Source}

National Cancer Institute. Neuropharmacology and Toxicology. NCI Thesaurus. Code C19615.

Research into the mechanisms of drug action and cellular neurotoxicity in brain cells. 